\title{
The Gendered Relationship Between (Old and New Forms of) Employment Instability and Union Dissolution
}

\author{
Elena Bastianelli ${ }^{1} \cdot$ Daniele Vignoli ${ }^{2}$
}

Received: 28 October 2020 / Accepted: 19 August 2021 / Published online: 30 August 2021

(c) The Author(s) 2021

\begin{abstract}
The present study contributes to a more comprehensive understanding of the relation between employment instability and union dissolution. To address the oversights of previous research, we disentangle the effect of employment instability on union dissolution by: (i) considering not only the effect of joblessness, but also the type of employment contract; (ii) evaluating both status and the accumulation of instability over the life course; and (iii) detecting gender differences. We focus on Italy, applying event-history techniques to the most recent Italian Multipurpose Survey "Families, social subjects and life cycle" of 2016, observing cohorts from 1950 to 1986. Our results suggest that the effect of employment instability on union dissolution is gender-specific: joblessness and limited-time employment are facilitators for men's dissolution, while, for women, joblessness is an inhibitor for dissolution, and time-limited and permanent employment do not substantially differ. We also highlight the crucial role of the persistence of instability in unpacking the association between employment instability and union dissolution. This paper advances-for the first time for Italy, at least-that men's time-limited employment arrangements negatively affect a couple's stability.
\end{abstract}

Keywords Union dissolution · Employment instability · Joblessness · Time-limited employment · Gender

Elena Bastianelli

elena.bastianelli@unito.it

1 Department of Cultures, Politics and Society, University of Turin, Campus Luigi Einaudi, Lungo Dora Siena, 100, 10153 Turin, Italy

2 Department of Statistics, Computer Science, Applications, University of Florence, Viale Giovanni Battista Morgagni, 59, 50134 Florence, Italy 


\section{Introduction}

Since the 1980s, capitalism and increasing globalization, and the consequent strong trends of deregulation, privatization, and the delocalization of economies- together with rapid technological advances - have fundamentally reshaped European labor markets (Mills \& Blossfeld, 2013; Mills et al., 2006; Vignoli et al., 2020a, 2020b). Exposure to global markets has promoted the diffusion of new forms of time-limited work contracts characterized by lower wages, decreased bargaining power, and diminished rights and social protection. These factors have served to transform labor market entry and exit conditions, and to destabilize the security of career paths (Barbieri \& Scherer, 2009; Ciganda, 2015; Grotti \& Scherer, 2014; Vignoli et al., 2016, 2020c). Furthermore, within the last two decades, the global economy has faced a series of transformations-culminating in the Great Recession, the most dramatic financial crisis in recent memory-which caused a drastic rise in unemployment, the spread of precarious work, and the volatility of household incomes (Bloom, 2014; Mills \& Blossfeld, 2013; Storesletten et al., 2004). Such changes generated an unprecedented level of economic uncertainty (Bauman, 2007; Vignoli et al., 2020a). While economic uncertainty has been shown to impact family dynamics (Kreyenfeld et al., 2012), the relationship between economic uncertainty and union dissolution has rarely been studied. The present paper adds to the growing literature on the nexus between economic uncertainty and family life courses by addressing the relationship between employment instability-considered a major proxy of economic uncertainty (Kreyenfeld et al., 2012) — and union dissolution.

Existing research indicates a theoretical ambivalence concerning the direction of the effects of employment instability on divorce. On one side, the relational stress hypothesis (Conger et al., 1990; Liker \& Elder, 1983) suggests that employment instability increases psychological distress and exacerbates marital discord, thus increasing the risk of divorce. Conversely, the cost of divorce perspective (Cherlin, 1979) argues that unfavorable economic conditions may reduce divorce by rising its relative cost, i.e., legal settlements, household relocation, or increasing the costs of consumer durables (Amato \& Beattie, 2010; Cohen, 2014; Fischer \& Liefbroer, 2006). The existing empirical evidence is as mixed as the theoretical expectations - in no small part due to a series of limitations.

First, virtually all prior research has only used unemployment as an indicator of economic performance. This is somewhat dismissive of the fact that employment instability is also engendered by time-limited work contracts; namely, jobs with short-terms contractual arrangements often characterized by insecurity, lack of rights and social protection, and generally low earnings, thereby favoring uncertain futures (Benach \& Muntaner, 2007; Benach et al., 2014; Pirani \& Salvini, 2015). We thus identify employment instability with joblessness and time-limited employment-both of which generate high levels of uncertainty since they correspond to a lack of clarity on economic prospects, as well as economic strain from either a total lack of income from work, or temporary (and often scarce) salaries.

Second, while the grand majority of past studies have considered measures of employment status (i.e., being unemployed), a series of recent papers have added 
that not only the status, but also — and especially - the persistence of employment instability affects family dynamics (Busetta et al., 2019; Ciganda, 2015; Özcan et al., 2010; Pailhé \& Solaz, 2012).

Third, prior research has generally lacked a gender perspective, despite it being already well-established that employment status may have a different meaning for women and men's partnership choices (de Rose \& Di Cesare, 2007; Sayer et al., 2011). In societies with a prevalent male-breadwinner family system, when the wife is not employed, her cost of divorce is typically higher since she is likely to be financially dependent on the marriage (Sayer \& Bianchi, 2000). Conversely, when the husband is jobless, the stress mechanisms may be predominant due to his poor performance as a provider (Cherlin, 1979; Conger et al., 1990). Most studies including gender comparisons (e.g., de Rose \& Di Cesare, 2007; Hansen, 2005; Jalovaara, 2003; Liker \& Elder, 1983; Ono, 1998; for Italy) date back to over a decade ago and, importantly, it has been shown that, as the economic role of men and women equalizes, gender differences gradually disappear (Hansen, 2005; Jalovaara, 2003; Oppenheimer, 1994). Therefore, as the economic roles and aspirations of men and women have tended to converge across generations, analyzing recent cohorts is especially crucial.

To address these oversights of past research, we hope to clarify the effect of employment instability on union dissolution by: (i) considering not only the effect of joblessness, but also the type of employment contract; (ii) evaluating both the status and accumulation of instability over the life course; and (iii) detecting gender differences. We use Italy as a meaningful case-study for multiple reasons. Marriage is still a dominant institution, and the diffusion of union dissolutions is limited compared to European standards. Nonetheless, trend data suggest there has been a strong increase in total divorce and separation rates in recent decades, mirrored by one of the fastest-growing spreads of temporary contractual arrangements in Europe, rising unemployment, and a slow and problematic convergence of gender roles. We apply event-history techniques to the recently released data of the 2016 Italian Multipurpose Survey "Families, social subjects and life cycle", conducted by the Italian National Institute of Statistics (Istat). The data are unique in providing high quality retrospective information on the occurrence of dissolutions over the past four decades. This is the first study to address union dissolution in Italy that encompasses the Great Recession.

\section{Background}

\section{Instability of Employment Careers and Union Dissolution}

At the individual level, unemployment has been repeatedly linked to union dissolution (Conger et al., 1990; Doiron \& Mendolia, 2012; Hansen, 2005; Jalovaara, 2003; Liker \& Elder, 1983; Ruggles, 1997; Starkey, 1996). In line with the relational stress hypothesis prior research identified several potential mechanisms which suggested unemployment's disruptive effects on marriage. 
One such mechanism outlines how surging financial pressures and loss of income due to unemployment may reduce marital quality. A sudden and unexpected reduction in income is likely to generate tension within a couple by disrupting the routines of family life (Conger et al., 1990; Liker \& Elder, 1983; Starkey, 1996). Research has shown that marital relations become strained and filled with conflict when couples are forced to adapt to a heavily reduced income (Liker \& Elder, 1983).

A second mechanism suggests that unemployment leads to lower levels of subjective well-being, manifested by higher psychological distress, frustration, and depression (Marsh \& Alvaro, 1990; Oesch \& Lipps, 2013; Whelan, 1994)—factors likely to facilitate marital conflict. Early studies in the United States found that unemployment had an indirect effect on marital quality through husbands' behavior (Atkinson et al., 1986; Conger et al., 1990; Liker \& Elder, 1983; Starkey, 1996). Husbands' employment instability negatively affected family interaction by increasing their irritability, explosiveness, and hostility, while simultaneously decreasing their levels of warmth and support toward their wives. In turn, men's hostility was associated with greater perceptions of marital instability by wives, and with lower levels of women's satisfaction or happiness (Conger et al., 1990).

A third mechanism links unemployment to certain individual psychological traits and characteristics which could also influence marital stability, such as personal inconstancy, mutability, or a lack of reliability or sense of responsibility (Atkinson et al., 1986; Charles \& Stephens, 2004; Doiron \& Mendolia, 2012). Therefore, joblessness could also be indicative of certain characteristics which affects a person's suitability as a mate. Doiron and Mendolia (2012), distinguishing between different types of job displacements (dismissal, redundancy, and the end of a temporary contract) among men in the UK, found support for this hypothesis. They showed that job losses dependent on the worker's characteristics (i.e., dismissals) more strongly impact marriages than redundancies, which instead depend on the employer's traits or circumstances.

As the majority of the presented research dates back to a few decades ago, it therefore does not account for time-limited jobs — which at the time played only a minor role in the job market. Within the definition of time-limited jobs (also named in the literature as "flexible", "precarious", or "non-standard" working contracts) are included fixed-term, job-on-call, job sharing, apprenticeship, training, project-based contracts and so forth, all implying a multidimensional concept including discontinuity in time, job insecurity, lack of social protection, and often low levels of wages and earnings (Benach \& Muntaner, 2007; Benach et al., 2014; Pirani \& Salvini, 2015). Time-limited contracts were proposed to reduce unemployment, simplify the transition between education and work, and as a mean to help families (generally women) reconcile work and family duties (Barbieri \& Scherer, 2009; Garibaldi \& Taddei, 2013; Naldini \& Saraceno, 2008). In many European countries, however, these goals have not been achieved, and these contracts have instead provoked increasing segmentation and dualization of labor markets, where time-limited workers are far less likely to find quality employment (Barbieri \& Cutuli, 2010; Barbieri \& Scherer, 2009). While time-limited jobs share some positive features with permanent employment (or, at the very least, help stave off unemployment), they also share certain unfavorable conditions with unemployment (Barbieri \& Scherer, 2009; Benach et al., 2014; Pirani \& Salvini, 2015). 
Several studies have in fact shown that time-limited contracts negatively impact private lives and health conditions. For instance, they have been shown to be associated with reductions in life satisfaction and subjective well-being, and increases in such psychological disorders as mental distress and depression (Benach \& Muntaner, 2007; Benach et al., 2014; Gash et al., 2007; Kim et al., 2008; Pirani \& Salvini, 2015; Scherer, 2009; Virtanen et al., 2005). It would be reasonable to argue, therefore, that some of the mechanisms described for unemployment may also apply to time-limited work. Indeed, time-limited work has been proven to contribute to increased work-family conflict and relationship strife (Scherer, 2009; Steiber, 2009), and decreased relationship satisfaction (Blom et al., 2020) which, as with unemployment, may serve to increase the risk of dissolution.

\section{Instability of Employment Careers: Status or Persistence?}

Joblessness and time-limited work contracts may have long-term negative consequences for employment prospects (Barbieri \& Scherer, 2009; Busetta et al., 2019). From a life course perspective, exposure to long spells of joblessness or time-limited work (particularly in one's early career) can be significantly detrimental as work experiences often follow from one another and people are increasingly directed into given trajectories, thereby leading to patterns of path dependency (Dannefer, 2003; Giesecke, 2003; Mynarska et al., 2015; Vignoli et al., 2020c). Prolonged exposure to unstable job positions has been shown to operate as a chronic stressor (Glavin, 2015), and, in some circumstances, its effects are not necessarily immediately perceived. Nonetheless, disadvantages related to unstable employment increase in line with its persistence (Kaplan \& Herbst-Debby, 2018). Following this idea, certain recent studies on the relation between employment instability and fertility (e.g., Busetta et al., 2019; Ciganda, 2015; Özcan et al., 2010; Pailhé \& Solaz, 2012) have suggested that family decisions are likely influenced not only by one's present circumstances, but by the information garnered from previous experiences and future prospects.

To the best of our knowledge, this is the first study to address the role of continued employment instability on union dissolution. Examining the role of its persistence allows us to acknowledge that the relationship between employment instability and union dissolution may be non-monotonic. A relatively short spell of joblessness or unstable positions may be insufficient to generate stress in a couple. Indeed, such misfortunes may even strengthen the bonds between a couple. However, should these periods expand, employment instability may exacerbate tensions within a couple and increase the risk of union dissolution.

\section{A Gender Lens}

The disruptive role of unemployment on marital stability has been generally discussed and tested from a predominantly male perspective. Nevertheless, from the few studies containing information on women, it appears that women's unemployment does not provoke the same level of familial strain (Liker \& Elder, 1983)—with 
the exception of a handful of studies from Scandinavia (Hansen, 2005; Jalovaara, 2003).

Under male-breadwinner family systems, where men are the main income providers and women, if employed at all, cover more alternative and "compensatory" economic roles, the financial strain on families is greater when the husband is unemployed (Liker \& Elder, 1983; Starkey, 1996). Nonetheless, jobless women, due to their high skills' specialization in care and domestic work rather than in the labor market, and lacking the economic means to live independently, face a higher cost of divorce (Cherlin, 1992; Sayer \& Bianchi, 2000; Todesco, 2009). Besides, more traditionally-minded women, for whom being outside the labor market is a "choice", by definition do not experience employment instability. When the man is jobless, by contrast, the stress mechanisms are typically predominant due to his poor performance as a provider (Cherlin, 1979; Killewald, 2016).

According to the gendered institution perspective, the risk of divorce within a couple is also dependent on the deviation from, or compliance with, the prevalent model, and divorce is more likely when spouses' employment and earnings violate gender norms. From this perspective, in societies still (relatively) traditional, a husband's unemployment and a wife's employment strain marriages by violating the implicit terms of the marital contract (Killewald, 2016; Sayer et al., 2011). The disruptive effect of this "violation" on marriages is thus claimed to be tied to traditional gender norms and ought to decrease in more gender equal societies. Previous studies focusing on the Italian context have reported an opposite association of men and women's employment status and dissolution risk (de Rose \& Di Cesare, 2007; Salvini \& Vignoli, 2011). However, the data used by such studies dates back to almost 20 years and, as the economic role of men and women have tended to equalize, the gendered relation between employment status and union dissolution might have changed.

\section{Italy, a Case Study}

Divorce was introduced in Italy on December 1, 1970 with law no. 898. This is significantly later than most European countries, where laws regulating divorce existed since the first half of the 20-th century or, in some cases, even earlier (González \& Viitanen, 2009). Up until the last two decades, Italian marital stability seemed to be an exception to the wider European landscape. Besides its relative lateness in introducing divorce, dissolution rates in Italy have always been low compared to most wealthy countries (Sobotka \& Toulemon, 2008). Nonetheless, divorce rates have been rising considerably, in line with shrinking marriage rates, to such an extent that in 2016 the number of divorces reached almost $50 \%$ of the number of marriages celebrated that year (Istat, 2016). Following the same tendency, non-marital cohabitations - a traditionally marginal phenomenon in Italy - have seen a considerably increase in recent decades, passing from 1.7\% of all couples in 1998 to $8.6 \%$ in 2016 (Istat, 2020).

Changes in relationship patterns have been mirrored by important shifts in the labor market. The Italian labor market was traditionally heavily regulated with 
strong employment protection legislation and a rigid system of wage determination (Garibaldi \& Taddei, 2013). Core labor market flexibilization reforms began in the 1980s and have led to a gradual liberalization of time-limited employment, as well as the progressive introduction of flexible contracts (relating to both working hours and employment duration) (Barbieri \& Scherer, 2009). The most significant steps in the process of deregulation/segmentation were taken in 1997 with the "Treu Law" (L.196/1997), and the subsequent "Biagi Law" (L.30/2003). These new regulations introduced and revised several forms of non-permanent contracts, i.e., job-on-call, job sharing, part-time, apprenticeship, training, timelimited, and project-based work-all of which are characterized by lower wages, inferior bargaining power, and decreased rights and social protection (Barbieri \& Scherer, 2009; Pirani \& Salvini, 2015; Vignoli et al., 2016). However, alongside this increased flexibilization, legislation for open-ended contracts has long remained substantially unmutated. The Italian reform process was thus defined as "marginal" or "targeted" (Barbieri \& Scherer, 2009; Garibaldi \& Taddei, 2013), since it applied only to new jobs, and affected only a fraction of the population. This has engendered a substantial labor market dualization: a "rigid" primary labor market, in which a core group of insiders hold stable and secure jobs (predominantly represented by adult men), and a residual "flexible" secondary labor market (overrepresented by women and young adults), typified by unstable jobs and long-lasting unemployment spells (Barbieri \& Scherer, 2009; Boeri et al., 2012; Garibaldi \& Taddei, 2013). Following the Great Recession, two reforms, known as the "Fornero Law" in 2012 and the "Jobs Act" in 2015, attempted to reduce this dual structure. Their goal was to provide incentives for companies to adopt more permanent employment contracts, and increase their flexibilization both in hiring and dismissal costs, and procedures. However, this objective was only marginally achieved (Boeri \& Garibaldi, 2019; Catalano \& Pezzolla, 2017).

From the early ' $80 \mathrm{~s}$, the Italian economy has been characterized by high unemployment and low employment rates as compared with other developed countries (Garibaldi \& Taddei, 2013). The liberalization of time-limited work contracts in the pre-recession period played a pivotal role in reducing unemployment levels by boosting hiring and job creation (Barbieri \& Sestito, 2008). Figure 1 shows the time trend of the share of time-limited work as a percentage of total employment. The spread of time-limited contracts in Italy has been one of the fastest-growing in Europe-much higher than the OECD average. However, at their termination, most time-limited contracts did not translate into permanent ones. In segmented labor markets (as in Italy), temporary work is often used by firms as a cheaper factor of production, thus taking advantage of the large regulatory gap with respect to permanent contracts (Garibaldi \& Taddei, 2013).

The Great Recession brought with it a sizable negative shock that strongly undermined Italy's labor market performance, leading to alarmingly high levels of unemployment, which only began to gradually recover from 2014 (Marino \& Nunziata, 2017). Indeed, most affected by the crisis were those with time-limited (and non-renewed) work contracts who were not covered by social protection schemes (Garibaldi \& Taddei, 2013). 


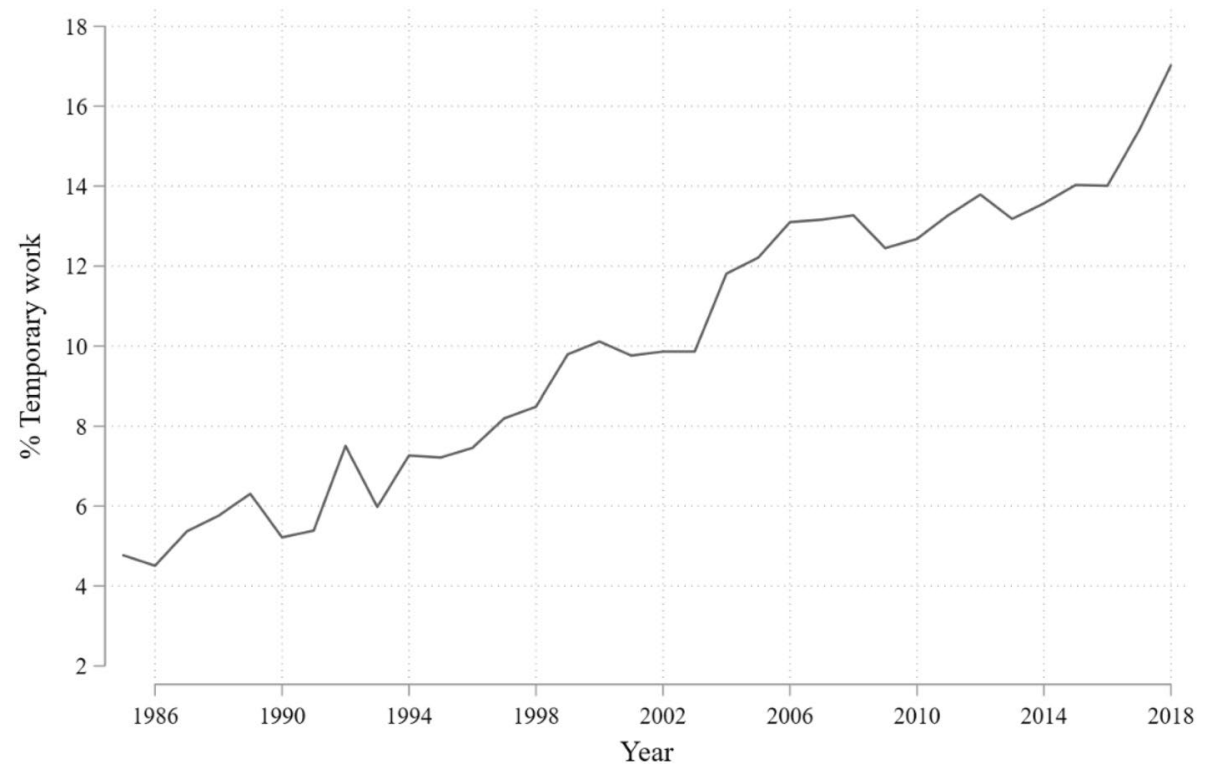

Fig. 1 Share of time-limited work as a \% of total employment. Source: Own elaboration of OECD data

The Italian labor market continues to contain sizeable gender differences in terms of employment rates. Although the gap between women's and men's employment rates has been slowly narrowing (women's employment has increased by approximately $12 \%$ in the last 20 years), the $20 \%$ employment gap remains a relevant gender difference (Istat, 2020). Furthermore, the reduction of this gap is partly due to a progressive decline in men's employment rates (Istat, 2020). Italian women continue to have one of the lowest labor force participation rates in the OECD, despite the number of women in tertiary education exceeding men (OECD, 2017). The country's average employment rate of women aged between 15 and 64 is currently 49.5\% (Istat, 2020). The growing (but still limited) participation of women in the labor market has been often attributed to the long tradition of a rigid familistic system (Reher, 1998), conservative expectations concerning familial responsibility, and the gender division of labor that has heavily influenced behaviors and policies (Knijn \& Saraceno, 2010). Italy continues to be one of the most asymmetrical countries in Europe regarding the division of domestic work-although important signs of change, especially among the most highly educated couples, are emerging (Dotti Sani, 2018). Policies aimed at promoting work-family balance and gender equality are still limited, and have been characterized by a certain degree of inertia in recent decades (Naldini \& Saraceno, 2008, 2011). 


\section{Hypotheses}

\section{Joblessness}

Since Italy still demonstrates relevant gender differences in the allocation of time and responsibilities between paid and unpaid work-and the prevalence of traditional gender attitudes - our first hypothesis (Hypothesis 1) is that the individuallevel relation between joblessness and union dissolution will likely still be the opposite for women and men. Jobless women should form more stable relationships than their permanently employed counterparts since they are economically dependent on their husbands and comply with traditional gender norms. Therefore, non-employed women should face a high economic and social cost of divorce. Conversely, women with permanent contracts (representing a select group of women), who enjoy greater economic independence, are therefore more likely to leave unhappy relationships since their cost of divorce is lower (Killewald, 2016; Sayer et al., 2011). Moreover, due to the general scarcity of reconciliation policies and family services, and the persistence of a gender ideology in the division of domestic labor and responsibilities, working women are more likely to experience work-family conflict, often resulting in high relational stress (Collins, 2020). It follows that jobless women are expected to be less likely to experience union dissolution than women with permanent contracts (Hypothesis 1a).

We expect to observe the opposite relation for men. Since, in Italy, men are expected to be a family's main provider, jobless men are more likely to exhibit stress and frustration (Kim \& Luke, 2020), thereby generating relationship conflict which, in turn, increases the risk of separation. Moreover, as jobless men in a dominant male-breadwinner context do not comply with gender norms, they can therefore be considered unsuitable husbands, further increasing relational stress. Conversely, men with secure jobs are likely to form more stable relationships as they fit the role of an effective family provider. Therefore, we expect jobless men to more frequently experience union dissolution than permanently employed men (Hypothesis $1 \mathrm{~b}$ ).

\section{Time-Limited Jobs}

Likewise, we anticipate a different relationship between time-limited contracts for women and men (Hypothesis 2). In the Italian context, time-limited forms of employment could represent an unfortunate "solution" to preserve the male-breadwinner family system by allowing women to combine work with domestic and care responsibilities, thus complying with existing gender norms (Kim et al., 2020). Consequently, these women should face lower levels of relational stress than their permanently employed counterparts. Moreover, since time-limited jobs often confer little-to-no economic independence, and are characterized by certain degrees of uncertainty, we expect women with time-limited work contracts to face a high cost of divorce due to their economic dependence. It follows that women with time-limited jobs should be less likely to experience union dissolution than permanently employed women (Hypothesis 2a). In a similar vein, women engaged in time-limited employment are 
expected to be less reliant on their husbands' economic support, making them more likely to experience union dissolution than jobless women. Moreover, as time-limited contracts offer a more flexible employment status compared to permanent employment - and are therefore less disruptive of traditional gender norms-we anticipate the union dissolution risk of women with time-limited contracts to be in between their jobless and permanently employed counterparts (Hypothesis $2 b$ ).

Men with time-limited contracts, instead, do not conform to their breadwinner roles and may engender economic hardship and uncertainty for the future of their families. This can lead to high relational stress and exacerbate tensions within couples, resulting in their dissolution. Therefore, time-limited employed men are expected to be more likely to experience union dissolution than permanently employed men (Hypothesis 2c). However, men with time-limited employment can at least financially contribute to the household to a certain extent (and so slightly conform to their breadwinner roles), especially compared to jobless males. We thus expect the union dissolution risk of men with time-limited employment in between their jobless and permanently employed counterparts (Hypothesis $2 \mathrm{~d}$ ).

\section{Accumulation of Employment Instability}

As observed in fertility research (Busetta et al., 2019; Özcan et al., 2010; Pailhé \& Solaz, 2012), the role of employment instability is likely dependent on its accumulation over a life course or, in the case of union dissolution, on the accumulation of employment instability over the time spent in a union (Hypothesis 3). Limited periods of joblessness or time-limited employment may in fact be a contingency, and thus, not necessarily influence union dissolution.

As for the previous hypotheses, we expect the effect to differ between genders. For women, the accumulation of jobless may increase economic dependence on their partners. Moreover, women in relationships who spend significant periods outside of the labor market could well be doing so out of a choice to dedicate more time to familial responsibilities. Consequently, we expect to observe a reduction in the risk of dissolution as time spent jobless increases (Hypothesis 3a). We expect a different association for the accumulation of time-limited jobs. While women engaged in time-limited work for a short period may not have the financial means with which to cope with a separation-especially compared with the permanently employedthose working in time-limited jobs for a considerable time may reach sufficient economic independence relative to women who do not engage in paid work at all. Accordingly, we expect the accumulation of time-limited work to gradually increase women's dissolution risk (Hypothesis $3 b$ ).

For men, a brief (or relatively short) length of time spent jobless or in unstable employment may be insufficient to generate significant levels of stress within a 
couple or to be reflective of their unsuitability as partners. On the contrary, a short spell of employment instability may serve to bring a couple together and strengthen family bonds during a challenging time. However, prolonged employment instability is likely to exacerbate relationship tension and increase the risk of dissolution. Therefore, according to the amount of time spent in employment instability, the effect may not be monotonic, but instead characterized by a "J-shaped" pattern (Hypothesis 3c).

Indeed, individuals with long spells of employment instability may be a very select group. For instance, women employed for less than half of the relationship may be a select, and more traditionally-minded, cluster, thereby less likely to dissolve a union. Similarly, men may experience long spells of unemployment due to their suffering from mental disorders or depression, which may also make them undesirable partners. Therefore, as we cannot control for the reason beyond the accumulation of unstable employment spells (see "Data and Methods"), we can only aim to uncover its potential association with union dissolution. A more formal test would necessarily require richer longitudinal data that are—as yet—unavailable for Italy.

\section{Data and Methods}

Our analysis makes use of micro data from Istat's nationally representative 2016 "Families, social subjects and life cycle" survey. The survey provides detailed (monthly) retrospective information on education, employment and career paths, fertility, and partnership histories. ${ }^{1}$ We followed an event-history continuous time approach to data analysis.

The event under study is the risk of union dissolution (including all first unions), be they cohabitations or marriages. Despite the vast differences between these two types in terms of stability, our choice to include both-and therefore to study union dissolution instead of divorce-was driven by an issue of selectivity, as it has been shown that younger couples (both within and outside of Italy) with unstable jobs generally tend to cohabit rather than marry (Manning, 2020; Vignoli et al., 2016). For non-marital cohabitations, union dissolution corresponds to the reported date of relationship termination and, for marriages, to the date of de facto separation, i.e., separations not yet accompanied by legal provision. For those cohabitations which result first in marriage and then in union dissolution, the event corresponds to the de facto separation from the marriage. The moment of de facto separation is in fact the moment that marks the marriage's dissolution and is consistent with the relationship terminations used for non-marital unions.

\footnotetext{
1 Respondents' employment history is based on the collection of employment episodes. The survey includes up to eleven employment episodes reported by respondents, with monthly-precise information on the begin and end of the employment spell. Individuals move from one episode to the next when their contracts end. Thus, to individuals with several job contracts corresponds several job episodes. In this way, also short-term transitions are captured in the analysis.
} 
We limited the analysis to working age population (between the ages of 15-60). Moreover, so as to differentiate between casual or fleeting relationships and committed unions, we excluded those who dissolved their union before their $20 \mathrm{~s}$, or those whose union lasted less than three months. Despite the capacity for individuals above the age of 60 still being active in the labor market, we excluded them from our analysis since they fall into the category of "gray divorces" (Brown \& Lin, 2012) itself a distinct phenomenon. We also cut our sample at 50 and 55 years old, and found that the results were substantially the same. Moreover, we excluded cohorts born before 1950 as divorce in Italy was possible only after 1970 and time-limited jobs have only been spreading since the 1980s. Additionally, we excluded cohorts born after 1986 as, at the time of the interview, they would have been too young to have experienced the event of union dissolution. The final sample consisted of $N=6612$ women and $N=5901$ men who entered a first union, including 9448 direct marriages, 1469 non-marital cohabitations, and 1596 cohabitations which resulted in marriages during the observation period. Of these, $N=1209$ women $(N=379$ cohabitations and $N=830$ marriages $)$ and $N=1155$ men $(N=493$ cohabitations and $N=662$ marriages) experienced union dissolution.

We employed an event-history model where the baseline risk was specified with a piecewise constant function. With such specifications, we assumed the risks of separation to be constant within each defined time period, yet we allowed for variation across periods. We measured all episodes in months since the beginning of a union.

We ought to reference certain data limitations upfront. First, the employment characteristics of ex-partners was unavailable to us, thereby excluding the possibility of a couple-level analysis. Moreover, despite the data providing detailed information on past and current employment spells, details on unemployment spells were lacking. Therefore, we could only see that the individual was not working, without being able to distinguish between inactivity or unemployment. However, joblessness, over unemployment, has been suggested to be more impactful when studying the consequences of economic constraints on family outcomes (Härkönen, 2011). Many of the social and demographic consequences of economic inactivity are identical to those of unemployment as the key point is whether a person is working, not whether they are actively looking for work. For this reason, many studies have expanded their focus to joblessness instead of unemployment (Busetta et al., 2019; Clasen et al., 2006). In line with this research, the lack of an indicator of personal unemployment should not compromise our analysis. Finally, despite the survey providing (subjective) information on the respondents' income, this was only collected at the time of the interview. As such, it would be incorrect to use this variable in the analysis because of the risk of performing a so-called "anticipatory analysis" (Hoem \& Kreyenfeld, 2006a, 2006b). Nevertheless, we controlled for the respondents' and their parents' levels of education as these are well-established proxies of socio-economic status (Barone, 2009; Koops et al., 2017).

To test our hypotheses, we built a number of key explanatory variables measuring different aspects of employment instability (c.f. Pailhé \& Solaz, 2012). To analyze the relation between current employment conditions and the risk of union dissolution, we built a time-varying variable identifying the respondents' type of contract, which we grouped as permanently employed (as a reference category), jobless, 
time-limited employed, and self-employed. Time-limited contractual arrangements include jobs-on-call, job sharing, apprenticeships, training, project-based contracts, seasonal work, and all other types of time-limited employment.

To assess the influence of employment instability accumulation over the course of a relationship, we constructed two additional indicators measuring: the number of months of joblessness; and the number of months working in time-limited jobs, over the total number of months since the beginning of the union. To more comprehensively understand the patterns of accumulation of employment instability, we coded the two ratios in categories measuring whether the respondent was never jobless (reference), jobless up to $25 \%$, between 25 and $50 \%$, or over $50 \%$ of the relationship duration. Similarly, for time-limited work, we measured whether the respondent was never in time-limited jobs (reference), up to $10 \%$, between 10 and $20 \%$, or over $20 \%$ of the relationship duration. ${ }^{2}$

The model equation also includes the primary correlates of union dissolutions as identified by the literature: years since union formation; type of union (marriage vs. cohabitation); number and age of children; cohort; parental education and separation; and macro-region (Amato and Beattie, 2010; Lyngstad \& Jalovaara, 2010; Vignoli \& Ferro, 2009). Years since union formation, type of union (marriage or cohabitation), and number and age of children are time-varying. After building union histories and selecting our sample, only the variables defining the type of union, parental union condition, and employment status presented missing values. For all three variables, these values were below $2 \%$, and somewhat equally distributed in terms of demographic and socio-economic characteristics. Hence, these cases been deleted from the analysis. A descriptive table with exposure time and occurrences (i.e., union dissolutions) for all variables can be found in Table 3 of the appendix.

\section{Results}

\section{The Gendered Effect of Joblessness and Time-Limited Employment}

As a first descriptive glance, Table 1 displays the time at risk, number of dissolutions, and absolute monthly risk of experiencing union dissolution for each employment category and contract type, separately for women and men. For women, the category with the highest rate of union dissolution is time-limited employment, followed by permanent employment, with joblessness displaying the lowest rate. We observed an opposite pattern for men: the category with the highest dissolution rate is jobless, closely followed by time-limited employment, while permanent and selfemployment have the lowest rates. However, these differences may be constituted by compositional effects that must be controlled for in a multivariate analysis.

\footnotetext{
2 The cut off points were located based on the variables distribution, through an exploratory ("backwise") approach, i.e., starting from a large amount of categories and then removing step-by-step nonmeaningful categories, with a rational of balancing parsimony and assuring a meaningful sample size. Slightly modifying the cut off points results were not affected (results available upon request).
} 
Table 1 Exposure time and risk of dissolution by employment status and type of contract

\begin{tabular}{llllll}
\hline $\begin{array}{l}\text { Employment status and } \\
\text { type of contract }\end{array}$ & Person-months & Dissolutions & $\begin{array}{l}\text { Absolut monthly } \\
\text { risk per 1000 }\end{array}$ & $\begin{array}{l}\text { 95\% confidence } \\
\text { interval }\end{array}$ \\
\hline Women & & & & & \\
Permanent & 634,936 & 585 & 0.9 & 0.0009 & 0.0010 \\
Jobless & 848,766 & 391 & 0.5 & 0.0004 & 0.0005 \\
Time-limited & 99,033 & 110 & 1.1 & 0.0009 & 0.0013 \\
Self-employed & 164,617 & 123 & 0.8 & 0.0006 & 0.0009 \\
Total & $1,747,352$ & 1209 & 0.7 & 0.0007 & 0.0007 \\
Men & & & & & 0.0007 \\
Permanent & 782,506 & 606 & 0.8 & 0.0010 & 0.0008 \\
Jobless & 164,420 & 194 & 1.2 & 0.0009 & 0.0014 \\
Time-limited & 79,505 & 89 & 1.1 & 0.0007 & 0.0009 \\
Self-employed & 334,063 & 266 & 0.8 & 0.0008 & 0.0009 \\
Total & $1,360,494$ & 1155 & 0.9 & & \\
\hline
\end{tabular}

Table 2 displays three subsequent models for women and men. The model parameters, produced as maximum-likelihood estimates, are shown in the form of relative risks. All models include the aforementioned individual-level control variables. Adding to these, model 1 reports the time-varying indicator of employment status and contract type. Model 2 instead measures employment instability through the two cumulative indicators on the percentage of time in the relationship time spent jobless and in time-limited employment. Lastly, model 3 includes all measures simultaneously to assess the each's importance conditional on the others.

Analyzing the results of model 1 , we note the confirmation of hypotheses 1-1b. The relation between joblessness and union dissolution is in fact opposite for women and men (Hypothesis 1); specifically, joblessness in women is associated with a $26 \%$ lower risk of dissolution compared with permanent employment (Hypothesis 1a), while this risk is $58 \%$ higher for men (Hypothesis 1b). Moreover, for men, time-limited employment is associated with a $37 \%$ higher risk of union dissolution, whereas the effect was not statistically precise for women. These findings offer support for hypotheses $2 \mathrm{c}$ and $2 \mathrm{~d}$, as time-limited employment for men is associated with a higher risk of union dissolution relative to permanent employment (Hypothesis 2c), but lower than joblessness (Hypothesis 2d). Such results highlight the importance of distinguishing between time-limited and permanent employment contracts when studying men's union dissolution. Hypotheses $2 \mathrm{a}$ and $2 \mathrm{~b}$, however, are unsupported in that we found no clear effects for women - the risk of union dissolution for timelimited employed women is not statistically different from permanent employees.

Model 2 measures employment instability through the two indicators of accumulation of joblessness and time-limited employment. For women, the accumulation of joblessness is linked to a lower risk of union dissolution. Relative to continuously employed women, the risk of union dissolution is $48 \%$ lower for women jobless for up to $25 \%$ of the union, and $38 \%$ lower for women outside of the labor force for over half of their union. Thus, women with spells of joblessness experience a lower 


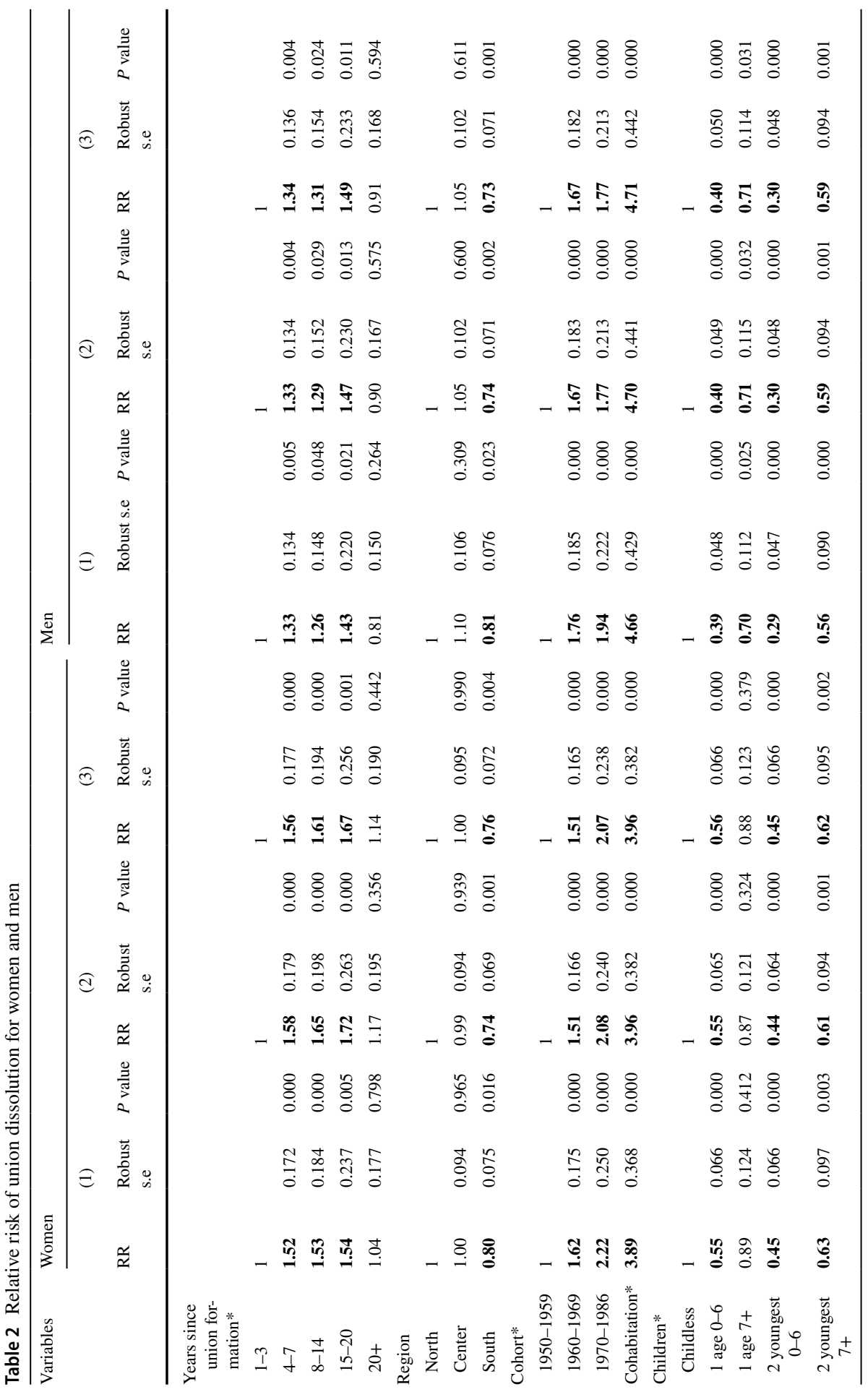




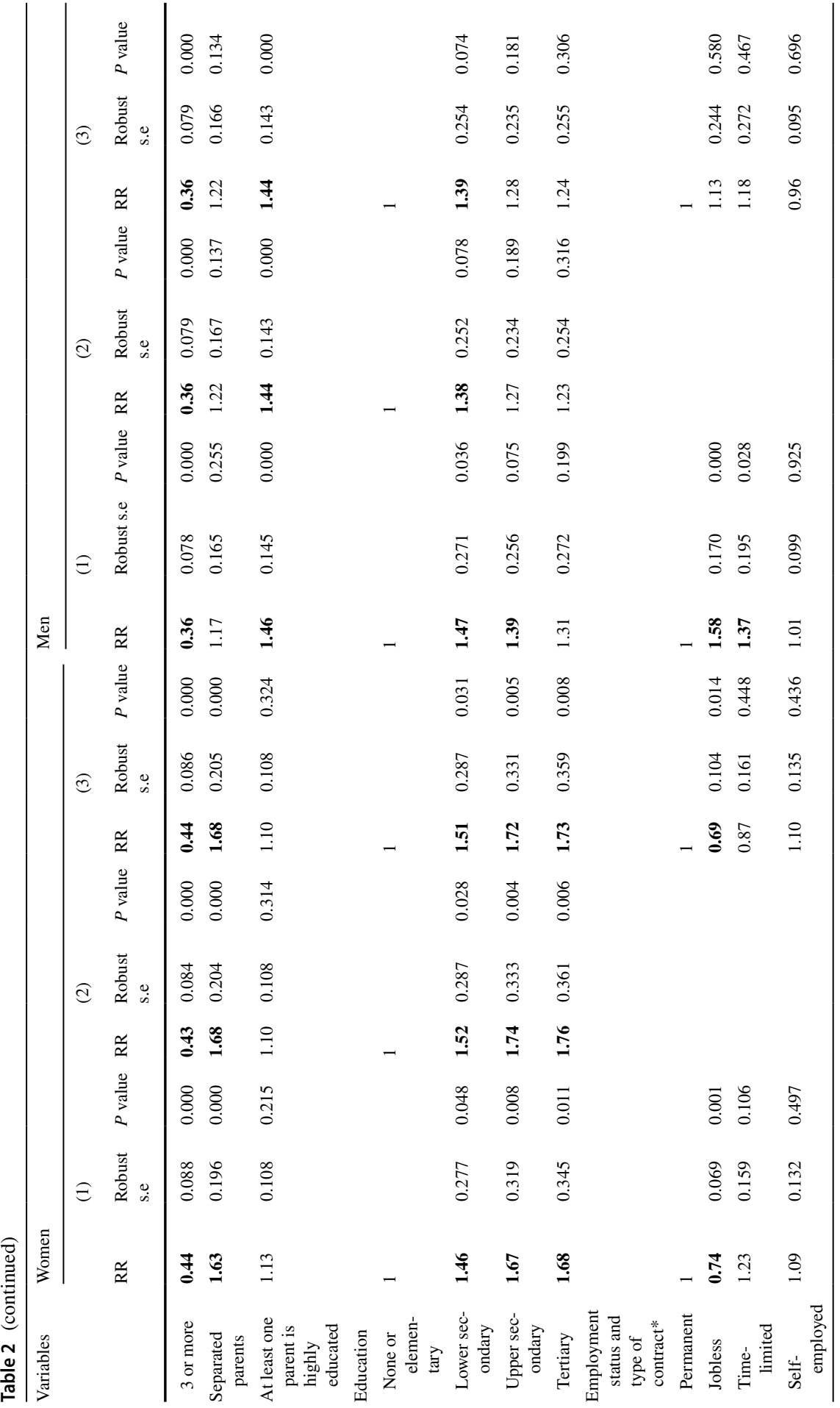




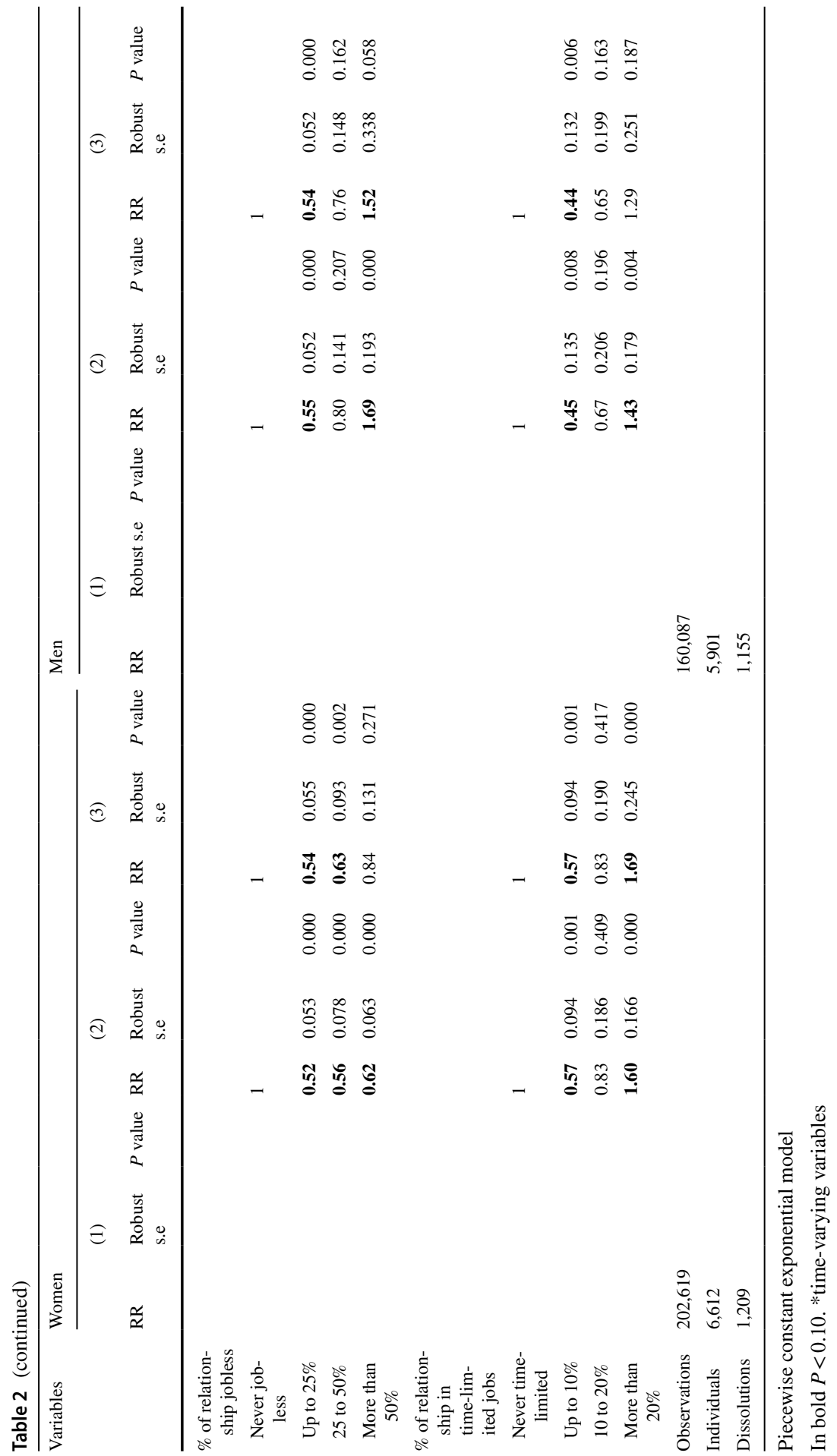




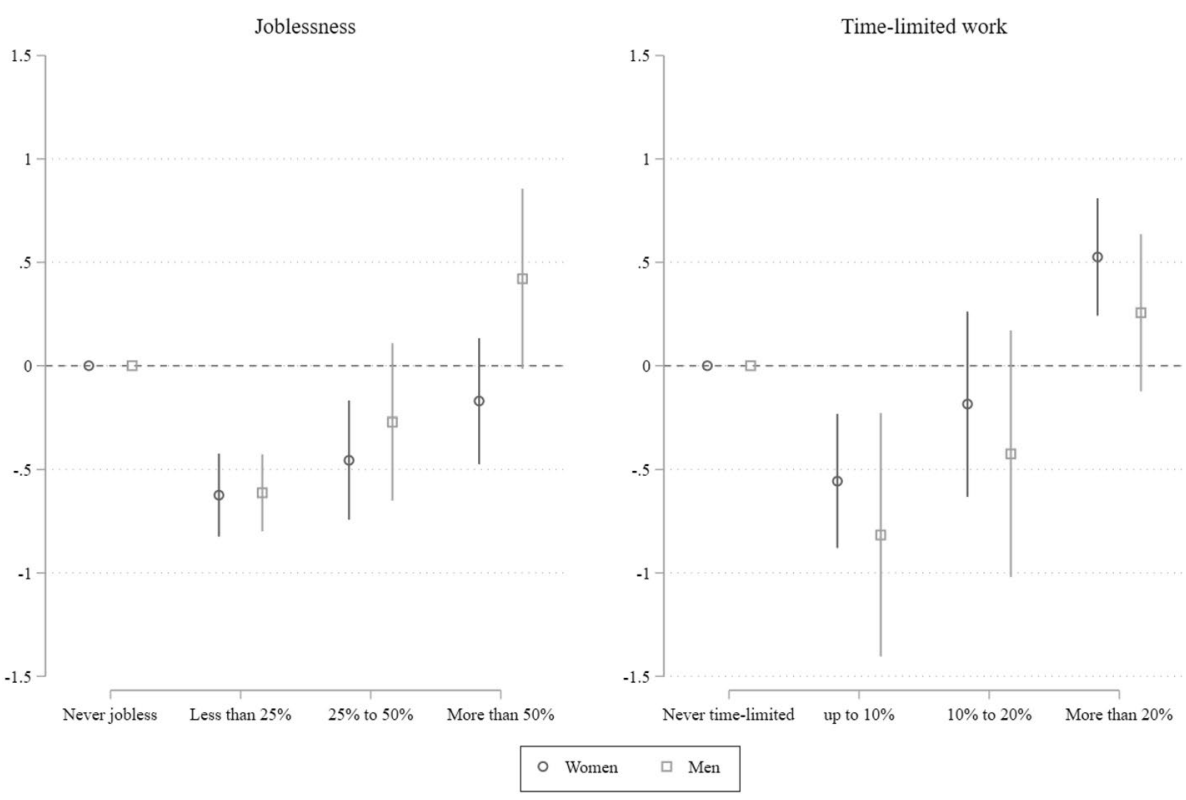

Fig. 2 Coefficients plot of union dissolution for women and men according to the accumulation of joblessness and time-limited work over the relationship. Source: Own computation of Istat survey data "Families, social subjects and life cycle" of 2016. Based on model 3

risk of union dissolution compared to those in continuous employment. However, in contrast to Hypothesis $3 \mathrm{a}$, the risk of union dissolution seems to slightly increase (instead of decrease) in line with time spent jobless in the relationship. Increasing the time spent in time-limited jobs is also associated with a gradual rise in women's risk of union dissolution, to the extent that women who engage in time-limited jobs for over one fifth of the relationship are approximately $60 \%$ more likely to experience union dissolution than those who have never worked time-limited jobs. In line with Hypothesis 3b, this result could be explained by the fact that, for women, working in time-limited jobs for considerable periods of time may actually increase their economic independence compared with women who do not engage in paid work at all. Our results suggest that, for Italian women, there is no clear difference in the association between permanent and time-limited contracts and union dissolution. Rather, whether a woman is employed or not is the more salient factor.

As we hypothesized, short periods of joblessness for men are instead associated with a lower risk of union dissolution, corresponding to a $45 \%$ risk reduction for those without a job for up to $25 \%$ of the relationship. However, men out of work for over half of their relationship can expect a $69 \%$ increase in the risk of union dissolution compared to those who never experience periods of joblessness. Thus, our results suggest that a considerable accumulation of joblessness for men is extremely detrimental for relationships. We observe a similar non-monotonic tendency for the accumulation of time-limited employment-which initially causes a 55\% risk reduction, followed by a $43 \%$ increase of the risk of dissolution after spending over $20 \%$ of the relationship in time-limited jobs. 
Model 3 includes all variables simultaneously. The results did not substantially differ from those presented in models 1 and 2. Generally, and in line with Hypothesis 3, the relation between employment instability and union dissolution seems to depend also on the former's accumulation over the time spent in the relationship (Fig. 2). However, more information about the factors beyond these periods of joblessness-i.e., whether it is voluntary or not-would be beneficial to more deeply explain these findings.

\section{Cause-Effect Ambiguity}

In this article, we have relied on the observed order of events (e.g., employment entry and union dissolution). It is worth considering that such a strategy may lead to an upward bias in the effect of women's employment on the risk of union dissolution if women increase their involvement in the labor market as a direct response to a decline in their relationship satisfaction and fear of union disruption (Oppenheimer et al., 1997; Özcan \& Breen, 2012; Vignoli et al., 2018). Support for such anticipatory adjustments can be found in the empirical literature for Italy (Vignoli et al., 2018). Thus, as a sensitivity check, we re-estimated a set of models excluding those women who entered the labor market during the three years preceding union disruption (the results of which, while not shown here, are available on request). While the results are substantially unchanged after excluding these cases, the estimated relative risk for jobless women is no longer statistically different from the permanently employed. This change suggests that women unsatisfied with their current relationships entered the labor market with a view to possible separation. Thus, without claiming causation, our results indicate a statistical association between women joblessness and union dissolution.

\section{Marriage-Cohabitation Differentials}

One final issue requires clarification. We included both married and cohabiting couples in our analysis as younger couples-overrepresented in unstable jobs-are usually more likely to cohabit rather than marry directly, or even marry at all (Manning, 2020; Vignoli et al., 2016). However, previous studies have reported that in contexts where cohabitation continues to be a marginal phenomenon (as is the case in Italy), cohabiting couples are often a self-selected group breaking the traditional view of marriage, including its gendered division of labor (Liefbroer \& Dourleijn, 2006; Meggiolaro \& Ongaro, 2019; Perelli-Harris et al., 2014). Therefore, we re-estimated model 1, augmented with an interaction term between union type and employment arrangements (see Appendix Table 4). The results were substantially the same, but with one exception. In contrast to married women, for cohabiting women, both joblessness and time-limited employment are associated with a higher risk of dissolution-just as with men. Therefore, the stabilizing effect of women's joblessness over their unions is driven by married women-consistent with the fact that they are likely to display more traditional family attitudes compared to their cohabiting counterparts. 


\section{Conclusion and Discussion}

The present study adds to the growing literature investigating the link between economic uncertainty and family dynamics by addressing the relationship between employment instability and union dissolution. Employment instability could either reduce the risk of union dissolution by rising its relative costs, or increase the risk by exacerbating stress and conflict within the relationship (Amato \& Beattie, 2010; Cohen, 2014; Fischer \& Liefbroer, 2006). The present study overcomes several limitations of prior research by providing novel evidence through the lens of gender. We studied the Italian context through the most reliable and extensive retrospective data available. These data allowed us to scrutinize the effect of time-constant and timevarying characteristics, and to observe cohorts from 1950 to 1986.

Our results suggest that, even when analyzing recent data, the effect of employment instability on union dissolution is gender-specific. We found joblessness to be a facilitator for men's dissolution and an inhibitor for women's dissolution. Moreover, men with time-limited contracts were found to have a far greater risk of dissolution than their permanently employed counterparts, while no clear pattern has been found for women. Thus, our findings highlight the importance of distinguishing between timelimited and permanent employment, especially when studying the risk of union dissolution for men. For women, however, there seems to be no clear divide in the association between permanent and time-limited work contracts and union dissolution, but the central factor is instead whether a woman is employed or not. In the Italian context, the gendered effect of employment instability on union dissolution is deeply rooted in relevant gender differences in the allocation of time and responsibilities between paid and unpaid work. Employment instability renders women economically dependent on their husbands, contributing to a rise in the economic and social cost of divorce. On the other hand, men's employment instability likely generates relational stress where the male partner is the main income provider. Additionally, in a dominant male-breadwinner context, men's employment instability clashes with prevailing gender norms.

Nonetheless, the relation between employment instability and union dissolution appears to be far more complex than one might assume at first glance. Without accounting for the persistence of employment instability, the emergent pattern is partial and simplistic. Indeed, our results show a non-monotonic relationship between employment instability and union dissolution. For women, the accumulation of periods of joblessness remains associated with a lower dissolution risk compared with women in continuous employment. However, a considerable accumulation of time spent in time-limited jobs is associated with a higher risk of union dissolution relative to those who have never worked in time-limited jobs. It could thus be argued that, for women, working in time-limited jobs for a considerable time may increase economic independence relative to those who do not engage in paid work at all. For men, instead, the initial effect of employment instability appears to be a rise in the cost of divorce, thereby substantially reducing the risk of dissolution. Only when the persistence of employment instability reaches a certain level does relational stress emerge and increase the risk of dissolution. In particular, a relevant accumulation of joblessness for men appears to be especially detrimental for relationships. On the whole, a "J-shaped" association emerges between 
instability of employment careers and union dissolution. It seems clear that individuals with accumulated employment instability are, in all probability, highly selected.

This article also contributes to Italian research on divorce. De Sandre (1980) was the first to show the increase in marital disruption among women of high socio-economic status in the first half of the 1970s - a finding later confirmed by, among others, De Rose (1992) on micro data. Later, other micro-level studies available for Italy all point to a positive gradient between women's socio-economic position and marital dissolution (Vignoli \& Ferro, 2009; Vignoli et al., 2018). Our findings confirm that, even among more recent cohorts, this situation remains substantially unchanged-at least regarding the role of women's employment status for marriage (and not for cohabitation) dissolutions. Moreover, prior studies that have compared men and women's employment statuses date back several decades - the last studies available made use of data from 1996 (de Rose \& di Cesare, 2007) to 2003 (Salvini \& Vignoli, 2011). Using data from 2016, our results reiterate previous evidence: being jobless increases the risk of union dissolution for men and reduces it among women, pinpointing a contemporary Italian society that remains somewhat traditional in terms of spouses' role sets.

Our study has its limitations. First, as the consulted survey does not include information on ex-partners, we were unable to explore both sides to the couples in the analysis. Accordingly, we could control only for the respondent's information in predicting dissolution risk. However, it has previously been suggested that information on both partners' contributions to paid and unpaid work are needed to properly assess the effect of women's employment on union dissolution (Mencarini \& Vignoli, 2018; Oláh \& Gahler, 2014; Sigle-Rushton, 2010). Second, the data do not allow us to distinguish unemployment from inactivity. Despite joblessness having been proven to be a valid indicator of employment instability in family research (Busetta et al., 2019; Härkönen, 2011), we acknowledge that unemployment and inactivity may have different roles in exacerbating stress or the cost of separation.

In all our study provides updated insights into the role of employment instability on union dissolution, and categorically rejects the notion of a unidirectional relationship. Our findings emphasize the importance of fully considering different dimensions of employment instability, including distinguishing between time-limited and permanent employment contracts, considering the role of instability accumulation throughout employment careers, and elucidating gender differences. We offer two novel findings. First, we show-for the first time for Italy, at least - that men's time-limited employment arrangements negatively impact a couple's stability. Second, our study represents a first attempt to include a measure of persistence of employment instability in the study of union dissolution. However, we acknowledge that more information on joblessness is needed to deepen our understanding of this relationship-i.e., whether it is voluntary or involuntary, or more income data in order to measure the individual means to cope with employment instability. Further research is necessary for a more in-depth examination of this association, as well as to understand whether our results can be extended to other countries and contexts.

\section{Appendix}

See Tables 3, 4. 
Table 3 Exposure and events

\begin{tabular}{|c|c|c|c|c|c|c|c|c|}
\hline & \multicolumn{2}{|c|}{$\begin{array}{l}\text { Women-months } \\
\text { observed in } \\
\text { union }\end{array}$} & \multicolumn{2}{|l|}{ Failures } & \multicolumn{2}{|c|}{$\begin{array}{l}\text { Men-months } \\
\text { observed in } \\
\text { union }\end{array}$} & \multicolumn{2}{|l|}{ Failures } \\
\hline & Abs. value & $\%$ & Abs. value & $\%$ & Abs. value & $\%$ & Abs. value & $\%$ \\
\hline \multicolumn{9}{|c|}{ Years since union* formation } \\
\hline $0-3$ & 232,496 & 13.3 & 243 & 20.1 & 204,247 & 15 & 337 & 29.2 \\
\hline $4-7$ & 287,884 & 16.5 & 295 & 24.4 & 245,063 & 18 & 291 & 25.2 \\
\hline $8-14$ & 429,582 & 24.6 & 325 & 26.9 & 356,067 & 26.2 & 260 & 22.5 \\
\hline $15-20$ & 290,214 & 16.6 & 187 & 15.5 & 231,123 & 17 & 154 & 13.3 \\
\hline $20+$ & 507,176 & 29 & 159 & 13.2 & 323,994 & 23.8 & 113 & 9.8 \\
\hline \multicolumn{9}{|l|}{ NUTS-1 region } \\
\hline North & 757,495 & 43.4 & 643 & 53.2 & 576,265 & 42.4 & 630 & 54.5 \\
\hline Center & 303,106 & 17.4 & 247 & 20.4 & 224,015 & 16.5 & 221 & 19.1 \\
\hline South and Islands & 686,751 & 39.3 & 319 & 26.4 & 560,214 & 41.2 & 304 & 26.3 \\
\hline \multicolumn{9}{|l|}{ Cohort } \\
\hline 1950-1959 & 767,060 & 43.9 & 227 & 18.8 & 621,462 & 45.7 & 262 & 22.7 \\
\hline 1960-1969 & 588,987 & 33.7 & 410 & 33.9 & 466,105 & 34.3 & 411 & 35.6 \\
\hline 1970-1986 & 391,305 & 22.4 & 572 & 47.3 & 272,927 & 20.1 & 482 & 41.7 \\
\hline \multicolumn{9}{|l|}{ Type of union* } \\
\hline Marriage & $1,651,275$ & 94.5 & 830 & 68.7 & $1,264,728$ & 93 & 662 & 57.3 \\
\hline Cohabitation & 96,077 & 5.5 & 379 & 31.4 & 95,766 & 7 & 493 & 42.7 \\
\hline \multicolumn{9}{|c|}{ Number and age of children* } \\
\hline Childless & 318,980 & 18.3 & 507 & 41.9 & 289,588 & 21.3 & 659 & 57.1 \\
\hline 1 age $0-6$ & 290,232 & 16.6 & 181 & 15 & 244,102 & 17.9 & 132 & 11.4 \\
\hline 1 age $7+$ & 234,384 & 13.4 & 181 & 15 & 162,385 & 11.9 & 112 & 9.7 \\
\hline 2 youngest $0-6$ & 260,693 & 14.9 & 109 & 9 & 217,133 & 16 & 75 & 6.5 \\
\hline 2 youngest $7+$ & 390,266 & 22.3 & 164 & 13.6 & 287,617 & 21.1 & 131 & 11.3 \\
\hline 3 or more & 252,797 & 14.5 & 67 & 5.5 & 159,669 & 11.7 & 46 & 4 \\
\hline \multicolumn{9}{|l|}{ Parents are separated } \\
\hline No & $1,667,020$ & 95.4 & 1060 & 87.7 & $1,302,431$ & 95.7 & 1059 & 91.7 \\
\hline Yes & 80,332 & 4.6 & 149 & 12.3 & 58,063 & 4.3 & 96 & 8.3 \\
\hline \multicolumn{9}{|c|}{$\begin{array}{l}\text { At least one parent with } \\
\text { higher education }\end{array}$} \\
\hline No & $1,514,463$ & 86.7 & 886 & 73.3 & $1,192,482$ & 87.7 & 875 & 75.8 \\
\hline Yes & 232,889 & 13.3 & 323 & 26.7 & 168,012 & 12.4 & 280 & 24.2 \\
\hline \multicolumn{9}{|l|}{ Education } \\
\hline None or primary & 244,985 & 14 & 52 & 4.3 & 130,603 & 9.6 & 47 & 4.1 \\
\hline Lower secondary & 598,304 & 34.2 & 304 & 25.2 & 510,890 & 37.6 & 391 & 33.9 \\
\hline Upper secondary & 656,118 & 37.6 & 581 & 48.1 & 561,252 & 41.3 & 528 & 45.7 \\
\hline Tertiary & 247,945 & 14.2 & 272 & 22.5 & 157,749 & 11.6 & 189 & 16.4 \\
\hline \multicolumn{9}{|c|}{$\begin{array}{l}\text { Employment status and type } \\
\text { of contract* }\end{array}$} \\
\hline Jobless & 848,766 & 48.6 & 391 & 32.3 & 164,420 & 12.1 & 194 & 16.8 \\
\hline Permanent worker & 634,936 & 36.3 & 585 & 48.4 & 782,506 & 57.5 & 606 & 52.5 \\
\hline
\end{tabular}


Table 3 (continued)

\begin{tabular}{|c|c|c|c|c|c|c|c|c|}
\hline & \multicolumn{2}{|c|}{$\begin{array}{l}\text { Women-months } \\
\text { observed in } \\
\text { union }\end{array}$} & \multicolumn{2}{|l|}{ Failures } & \multicolumn{2}{|c|}{$\begin{array}{l}\text { Men-months } \\
\text { observed in } \\
\text { union }\end{array}$} & \multicolumn{2}{|l|}{ Failures } \\
\hline & Abs. value & $\%$ & Abs. value & $\%$ & Abs. value & $\%$ & Abs. value & $\%$ \\
\hline Time-limited & 99,033 & 5.7 & 110 & 9.1 & 79,505 & 5.8 & 89 & 7.7 \\
\hline Self-employed & 164,617 & 9.4 & 123 & 10.2 & 334,063 & 24.6 & 266 & 23 \\
\hline \multicolumn{9}{|l|}{$\%$ Joblessness } \\
\hline Never & 273,259 & 15.6 & 384 & 31.8 & 584,915 & 43 & 628 & 54.4 \\
\hline Up to $25 \%$ & 467,286 & 26.7 & 281 & 23.3 & 590,054 & 43.4 & 291 & 25.2 \\
\hline 25 to $50 \%$ & 196,901 & 11.3 & 122 & 10.1 & 78,556 & 5.8 & 58 & 5 \\
\hline More than $50 \%$ & 809,906 & 46.4 & 422 & 34.9 & 106,969 & 7.9 & 178 & 15.4 \\
\hline \multicolumn{9}{|l|}{$\%$ Time-limited } \\
\hline Never & $1,390,237$ & 79.6 & 942 & 77.9 & $1,155,247$ & 84.9 & 983 & 85.1 \\
\hline Up to $10 \%$ of time & 137,287 & 7.9 & 54 & 4.5 & 60,462 & 4.4 & 19 & 1.6 \\
\hline 10 to $20 \%$ & 59,880 & 3.4 & 40 & 3.3 & 31,691 & 2.3 & 15 & 1.3 \\
\hline More than $20 \%$ & 159,948 & 9.2 & 173 & 14.3 & 113,094 & 8.3 & 138 & 12 \\
\hline
\end{tabular}

*Time-varying variables

Table 4 Relative risk of union dissolution for women and men, differences between married and cohabiting couples

\begin{tabular}{|c|c|c|c|c|c|c|}
\hline \multirow[b]{2}{*}{ Variables } & \multicolumn{3}{|l|}{ Women } & \multicolumn{3}{|l|}{ Men } \\
\hline & $\mathrm{RR}$ & Robust s.e & $P$ value & $\mathrm{RR}$ & Robust s.e & $P$ value \\
\hline Married & 1 & & & 1 & & \\
\hline Cohabiting & 2.73 & 0.334 & 0.000 & 4.87 & 0.585 & 0.000 \\
\hline Married * Permanent & 1 & & & 1 & & \\
\hline Married * Jobless & 0.58 & 0.061 & 0.000 & 1.38 & 0.204 & 0.032 \\
\hline Married * Time-limited & 0.96 & 0.164 & 0.821 & 1.31 & 0.264 & 0.173 \\
\hline Married * Self-employed & 0.91 & 0.130 & 0.511 & 1.20 & 0.137 & 0.116 \\
\hline Cohabiting * Permanent & 1 & & & 1 & & \\
\hline Cohabiting * Jobless & 1.33 & 0.219 & 0.086 & 1.76 & 0.274 & 0.000 \\
\hline Cohabiting $*$ Time-limited & 1.82 & 0.371 & 0.003 & 1.40 & 0.285 & 0.095 \\
\hline Cohabiting * Self-employed & 1.50 & 0.334 & 0.068 & 0.76 & 0.127 & 0.102 \\
\hline Observations & 202,619 & & & 160,087 & & \\
\hline Individuals & 6612 & & & 5901 & & \\
\hline Dissolutions & 1209 & & & 1155 & & \\
\hline
\end{tabular}

Piecewise constant exponential model

In bold $P<0.10$. Controlled for all variables included in Table 3 
Funding Open access funding provided by Università degli Studi di Torino within the CRUI-CARE Agreement. The authors acknowledge the financial support provided by: (i) the European Union's Horizon 2020 research and innovation programme/ERC Grant Agreement No 725961 (EU-FER project "Economic Uncertainty and Fertility in Europe," PI: Daniele Vignoli); (ii) the Italian Ministry of University and Research, 2018 FARE grant "Narratives" (PI: Daniele Vignoli); and (iii) the Italian Ministry of University and Research, 2017 MiUR-PRIN Grant “The Great Demographic Recession” Prot. No. 2017W5B55Y (PI: Daniele Vignoli).

Data Availability Data for this paper were obtained from the Italian National Statistical Office survey "Family and Social Subjects", available at https://www.istat.it/it/archivio/236637 upon request.

Code Availability The STATA code used in the current study is available from the corresponding author on reasonable request.

\section{Declarations}

Conflict of interest The authors declare that they have no competing interests.

Open Access This article is licensed under a Creative Commons Attribution 4.0 International License, which permits use, sharing, adaptation, distribution and reproduction in any medium or format, as long as you give appropriate credit to the original author(s) and the source, provide a link to the Creative Commons licence, and indicate if changes were made. The images or other third party material in this article are included in the article's Creative Commons licence, unless indicated otherwise in a credit line to the material. If material is not included in the article's Creative Commons licence and your intended use is not permitted by statutory regulation or exceeds the permitted use, you will need to obtain permission directly from the copyright holder. To view a copy of this licence, visit http://creativecommons.org/licen ses/by/4.0/.

\section{References}

Amato, P. R., \& Beattie, B. (2010). Does the unemployment rate affect the divorce rate? An analysis of state data 1960-2005. Social Science Research, 40, 705-715. https://doi.org/10.1016/j.ssresearch. 2010.12.012.

Atkinson, T., Liem, R., \& Liem, J. H. (1986). The social costs of unemployment: Implications for social support. Journal of Health and Social Behavior, 27(4), 317. https://doi.org/10.2307/2136947.

Barbieri, G., \& Sestito, P. (2008). Temporary workers in Italy: Who are they and where they end up. Labour, 22(1), 127-166. https://doi.org/10.1111/j.1467-9914.2007.00402.x.

Barbieri, P., \& Cutuli, G. (2010). A uguale lavoro, paghe diverse. Differenziali salariali e lavoro a termine nel mercato del lavoro italiano. Stato e Mercato, 3, 471-504. https://doi.org/10.1425/33150.

Barbieri, P., \& Scherer, S. (2009). Labour market flexibilization and its consequences in Italy. European Sociological Review, 25(6), 677-692. https://doi.org/10.1093/esr/jcp009.

Barone, C. (2009). A new look at schooling inequalities in Italy and their trends over time. Research in Social Stratification and Mobility, 27(2), 92-109. https://doi.org/10.1016/j.rssm.2009.04.001.

Bauman, Z. (2007). Liquid times: Living in an age of uncertainty. Cambrige: Polity Press.

Benach, J., \& Muntaner, C. (2007). Precarious employment and health: Developing a research agenda. Journal of Epidemiology \& Community Health, 61(4), 276-277. https://doi.org/10.1136/jech.2005. 045237.

Benach, J., Vives, A., Amable, M., Vanroelen, C., Tarafa, G., \& Muntaner, C. (2014). Precarious employment: Understanding an emerging social determinant of health. Annual Review of Public Health, 35(1), 229-253. https://doi.org/10.1146/annurev-publhealth-032013-182500. 
Blom, N., Verbakel, E., \& Kraaykamp, G. (2020). Couples' job insecurity and relationship satisfaction in The Netherlands. Journal of Marriage and Family, 82(3), 875-891. https://doi.org/10.1111/jomf. 12649.

Bloom, N. (2014). Fluctuations in uncertainty. Journal of Economic Perspectives, 28(2), 153-176. https:// doi.org/10.1257/jep.28.2.153.

Boeri, T., Conde-Ruiz, J. I., \& Galasso, V. (2012). The political economy of flexicurity. Journal of the European Economic Association, 10(4), 684-715. https://doi.org/10.1111/j.1542-4774.2012. 01065.x.

Boeri, T., \& Garibaldi, P. (2019). A tale of comprehensive labor market reforms: Evidence from the Italian jobs act. Labour Economics, 59, 33-48. https://doi.org/10.1016/j.labeco.2019.03.007.

Brown, S. L., \& Lin, I.-F. (2012). The gray divorce revolution: Rising divorce among middle-aged and older adults, 1990-2010. The Journals of Gerontology Series b: Psychological Sciences and Social Sciences, 67(6), 731-741. https://doi.org/10.1093/geronb/gbs089.

Busetta, A., Mendola, D., \& Vignoli, D. (2019). Persistent joblessness and fertility intentions. Demographic Research, 40, 185-218. https://doi.org/10.4054/DemRes.2019.40.8.

Catalano, M., \& Pezzolla, E. (2017). The Italian labor market reform: An evaluation of the jobs act using the prometeia DSGE model. Italian Economic Journal, 3(2), 209-238. https://doi.org/10.1007/ s40797-017-0057-z.

Charles, K. K., \& Stephens, M. (2004). Job displacement, disability, and divorce. Journal of Labor Economics, 22(2), 34.

Cherlin, A. J. (1979). Work life and marital dissolution. In G. Levinger \& O. C. Moles (Eds.), Divorce and separation (pp. 151-166). Basic Books.

Cherlin, A. J. (1992). Social trends in the United States. Marriage, divorce, remarriage (Rev. And enl. Ed.). Harvard University Press.

Ciganda, D. (2015). Unstable work histories and fertility in France: An adaptation of sequence complexity measures to employment trajectories. Demographic Research, 32, 843-876.

Clasen, J., Davidson, J., Ganßmann, H., \& Mauer, A. (2006). Non-employment and the welfare state: The United Kingdom and Germany compared. Journal of European Social Policy, 16(2), 134-154. https://doi.org/10.1177/0958928706062503.

Cohen, P. N. (2014). Recession and divorce in the United States, 2008-2011. Population Research and Policy Review, 33(5), 615-628. https://doi.org/10.1007/s11113-014-9323-z.

Collins, C. (2020). Who to blame and how to solve it: Mothers' perceptions of work-family conflict across western policy regimes. Journal of Marriage and Family, 82(3), 849-874. https://doi.org/10. 1111/jomf.12643.

Conger, R. D., Elder, G. H., Lorenz, F. O., Conger, K. J., Simons, R. L., Whitbeck, L. B., Huck, S., \& Melby, J. N. (1990). Linking economic hardship to marital quality and instability. Journal of Marriage and Family, 52(3), 643-656. https://doi.org/10.2307/352931.

Dannefer, D. (2003). Cumulative advantage/disadvantage and the life course: Cross-fertilizing age and social science theory. The Journals of Gerontology Series B: Psychological Sciences and Social Sciences, 58(6), S327-S337. https://doi.org/10.1093/geronb/58.6.S327.

De Sandre, P. (1980) Il rapporto sulla popolazione in Italia: esiti collettivi di un modo di vivere. Vita e pensiero, 11

de Rose, A., \& Di Cesare, M. (2007). Gender and first union dissolution. In A. Pinnelli, F. Racioppi, \& R. Rettaroli (Eds.), Genders in the life course (Vol. 19, pp. 167-184). Springer Netherlands.

Doiron, D., \& Mendolia, S. (2012). The impact of job loss on family dissolution. Journal of Population Economics, 25(1), 367-398. https://doi.org/10.1007/s00148-010-0353-5.

Dotti Sani, G. M. (2018). Time use in domestic settings throughout the life course. The Italian case. Springer Berlin Heidelberg.

Fischer, T., \& Liefbroer, A. C. (2006). For richer, for poorer: the impact of macroeconomic conditions on union dissolution rates in the Netherlands 1972-1996. European Sociological Review, 22(5), 519532. https://doi.org/10.1093/esr/jc1013.

Garibaldi, P., \& Taddei, F. (2013). Italy: A dual labour market in transition (Employment Working Paper No. 144). Geneva: International Labor Organization.

Gash, V., Mertens, A., \& Gordo, L. R. (2007). Are fixed-term jobs bad for yout health? A comparison of Weste Germany and Spain. European Societies, 9(3), 429-458. https://doi.org/10.1080/1461669070 1314150 .

Giesecke, J. (2003). Temporary employment: Chance or risk? European Sociological Review, 19(2), 161177. https://doi.org/10.1093/esr/19.2.161. 
Glavin, P. (2015). Perceived job insecurity and health: Do duration and timing matter? The Sociological Quarterly, 56(2), 300-328. https://doi.org/10.1111/tsq.12087.

González, L., \& Viitanen, T. K. (2009). The effect of divorce laws on divorce rates in Europe. European Economic Review, 53(2), 127-138. https://doi.org/10.1016/j.euroecorev.2008.05.005.

Grotti, R., \& Scherer, S. (2014). Accumulation of employment instability among partners-evidence from six EU countries. European Sociological Review, 30(5), 627-639. https://doi.org/10.1093/esr/ jcu063.

Hansen, H.-T. (2005). Unemployment and marital dissolution: A panel data study of Norway. European Sociological Review, 21(2), 135-148.

Härkönen, J. (2011). Children and dual worklessness in Europe: A comparison of nine countries: Enfants et couples sans emploi en Europe: Une comparaison entre neuf pays. European Journal of Population/Revue Européenne de Démographie, 27(2), 217-241. https://doi.org/10.1007/ s10680-011-9232-3.

Hoem, J. M., \& Kreyenfeld, M. (2006). Anticipatory analysis and its alternatives in life-course research. Part 1: Education and first childbearing. Demographic Research, 15(16), 461-484.

Hoem, J. M., \& Kreyenfeld, M. (2006). Anticipatory analysis and its alternatives in life-course research. Part 2: Marriage and first birth. Demographic Research, 15(17), 485-498. https://doi.org/10.4054/ DemRes.2006.15.17.

Istat. (2016). Matrimoni, separazioni e divorzi. Statistiche Report. https://www.istat.it/it/archivio/253756.

Istat. (2020). ISTAT data. http://dati.istat.it . Accessed on October 2020.

Jalovaara, M. (2003). The joint effects of marriage partners' socioeconomic positions on the risk of divorce. Demography, 40(1), 67-81.

Kaplan, A., \& Herbst-Debby, A. (2018). Fragile employment, liquid love: Employment Instability and divorce in Israel. Population Research and Policy Review, 37(1), 1-31. https://doi.org/10.1007/ s11113-017-9444-2.

Killewald, A. (2016). Money, work, and marital stability: Assessing change in the gendered determinants of divorce. American Sociological Review, 81(4), 696-719. https://doi.org/10.1177/0003122416655340.

Kim, J., \& Luke, N. (2020). Men's economic dependency, gender ideology, and stress at midlife. Journal of Marriage and Family, 82(3), 1026-1040. https://doi.org/10.1111/jomf.12615.

Kim, J., Henly, J. R., Golden, L. M., \& Lambert, S. J. (2020). Workplace flexibility and worker wellbeing by gender. Journal of Marriage and Family, 82(3), 892-910. https://doi.org/10.1111/jomf. 12633.

Kim, M.-H., Kim, C., Park, J.-K., \& Kawachi, I. (2008). Is precarious employment damaging to self-rated health? Results of propensity score matching methods, using longitudinal data in South Korea. Social Science \& Medicine, 67(12), 1982-1994. https://doi.org/10.1016/j.socscimed.2008.09.051.

Knijn, T., \& Saraceno, C. (2010). Changes in the regulation of responsibilities towards childcare needs in Italy and the Netherlands: Different timing, increasingly different approaches. Journal of European Social Policy, 20(5), 444-455. https://doi.org/10.1177/0958928710380481.

Koops, J. C., Liefbroer, A. C., \& Gauthier, A. H. (2017). The influence of parental educational attainment on the partnership context at first birth in 16 western societies. European Journal of Population, 33(4), 533-557. https://doi.org/10.1007/s10680-017-9421-9.

Kreyenfeld, M., Andersson, G., \& Pailhé, A. (2012). Economic uncertainty and family dynamics in Europe: Introduction. Demographic Research, 27, 835-852. https://doi.org/10.4054/DemRes.2012.27.28.

Liefbroer, A. C., \& Dourleijn, E. (2006). Unmarried cohabitation and union stability: Testing the role of diffusion using data from 16 European countries. Demography, 43(2), 203-221.

Liker, J. K., \& Elder, G. H. (1983). Economic hardship and marital relations in the 1930s. American Sociological Review, 48(3), 343. https://doi.org/10.2307/2095227.

Lyngstad, T. H., \& Jalovaara, M. (2010). A review of the antecedents of union dissolution. Demographic Research, 23, 257-292.

Manning, W. D. (2020). Young adulthood relationships in an era of uncertainty: A case for cohabitation. Demography, 57(3), 799-819. https://doi.org/10.1007/s13524-020-00881-9.

Marino, F., \& Nunziata, L. (2017). The labor market in Italy, 2000-2016. IZA World of Labor. https://doi.org/ 10.15185/izawol.407.

Marsh, C., \& Alvaro, J. L. (1990). A cross-cultural perspective on the social and psychological distress caused by unemployment: A comparison of Spain and the United Kingdom. European Sociological Review, 6(3), 237-256. https://doi.org/10.1093/oxfordjournals.esr.a036564.

Meggiolaro, S., \& Ongaro, F. (2019). The involvement in childcare of married and cohabiting fathers: Evidence from Italy. Genus. https://doi.org/10.1186/s41118-018-0051-9. 
Mencarini, L., \& Vignoli, D. (2018). Employed women and marital union stability: It helps when men help. Journal of Family Issues, 39(5), 1348-1373. https://doi.org/10.1177/0192513X17710283.

Mills, M., Blossfeld, H.-P., \& Bernardi, F. (2006). Globalization, uncertainty and men's employment careers. A theoretical framework. Globalization, Uncertainty, and Men's Careers: An International Comparison.

Mills, M., \& Blossfeld, H.-P. (2013). The second demographic transition meets globalization: A comprehensive theory to understand changes in family formation in an era of rising uncertainty. In T. Malfoy (Ed.), Negotiating the life course. Stability and change in life pathways. Springer.

Mynarska, M., Matysiak, A., Rybińska, A., Tocchioni, V., \& Vignoli, D. (2015). Diverse paths into childlessness over the life course. Advances in Life Course Research, 25, 35-48. https://doi.org/10.1016/j.alcr. 2015.05.003.

Naldini, M., \& Saraceno, C. (2011). Conciliare famiglia e lavoro. Vecchi e nuovi patti tra sessi e generazioni. Il Mulino.

Naldini, M., \& Saraceno, C. (2008). Social and family policies in Italy: Not totally frozen but far from structural reforms. Social Policy \& Administration, 42(7), 733-748. https://doi.org/10.1111/j.1467-9515. 2008.00635.x.

OECD. (2017). The Pursuit of Gender Equality: An Uphill Battle. Paris: OECD Publishing. https://doi.org/ 10.1787/9789264281318-en.

Oesch, D., \& Lipps, O. (2013). Does unemployment hurt less if there is more of it around? A panel analysis of life satisfaction in Germany and Switzerland. European Sociological Review, 29(5), 955-967. https:// doi.org/10.1093/esr/jcs071.

Oláh, L. S., \& Gahler, M. (2014). Gender equality perceptions, division of paid and unpaid work, and partnership dissolution in Sweden. Social Forces, 93(2), 571-594. https://doi.org/10.1093/sf/sou066.

Ono, H. (1998). Husbands' and wives' resources and marital dissolution. Journal of Marriage and Family, 60(3), 674-689. https://doi.org/10.2307/353537.

Oppenheimer, V. (1994). Women's rising employment and the future of the family in industrial societies. Population and Development Review, 20(2), 293-342. https://doi.org/10.2307/2137521.

Oppenheimer, V. K., Kalmijn, M., \& Lim, N. (1997). Men's career development and marriage timing during a period of rising inequality. Demography, 34(3), 311. https://doi.org/10.2307/3038286.

Özcan, B., \& Breen, R. (2012). Marital instability and female labor supply. Annual Review of Sociology, 38(1), 463-481. https://doi.org/10.1146/annurev-soc-071811-145457.

Özcan, B., Mayer, K. U., \& Luedicke, J. (2010). The impact of unemployment on the transition to parenthood. Demographic Research, 23, 807-846. https://doi.org/10.4054/DemRes.2010.23.29.

Pailhé, A., \& Solaz, A. (2012). The influence of employment uncertainty on childbearing in France: A tempo or quantum effect? Demographic Research, 26, 1-40. https://doi.org/10.4054/DemRes.2012.26.1.

Perelli-Harris, B., Mynarska, M., Berrington, A., Berghammer, C., Evans, A., Isupova, O., Keizer, R., Klärner, A., Lappegård, T., \& Vignoli, D. (2014). Towards a new understanding of cohabitation: Insights from focus group research across Europe and Australia. Demographic Research, 31, 1043-1078.

Pirani, E., \& Salvini, S. (2015). Is temporary employment damaging to health? A longitudinal study on Italian workers. Social Science \& Medicine, 124, 121-131. https://doi.org/10.1016/j.socscimed.2014.11. 033.

Reher, D. S. (1998). Family ties in western Europe: Persistent contrasts. Population and Development Review, 24(2), 203. https://doi.org/10.2307/2807972.

Ruggles, S. (1997). The rise of divorce and separation in the United States 1880-1990. Demography, 34(4), $455-466$.

Salvini, S., \& Vignoli, D. (2011). Things change: Women's and men's marital disruption dynamics in Italy during a time of social transformations, 1970-2003. Demographic Research, 24, 145-174. https://doi.org/10.4054/DemRes.2011.24.5.

Sayer, L. C., \& Bianchi, S. M. (2000). Women's economic independence and the probability of divorce. A review and riexamination. Journal of Family Issues, 21(7), 906-943.

Sayer, L. C., England, P., Allison, P. D., \& Kangas, N. (2011). She left, he left: How employment and satisfaction affect women's and men's decisions to leave marriages. American Journal of Sociology, 116(6), 1982-2018. https://doi.org/10.1086/658173.

Scherer, S. (2009). The social consequences of insecure jobs. Social Indicators Research, 93(3), 527-547. https://doi.org/10.1007/s11205-008-9431-4.

Sigle-Rushton, W. (2010). Men's unpaid work and divorce: Reassessing specialization and trade in British families. Feminist Economics, 16(2), 1-26. https://doi.org/10.1080/13545700903448801. 
Sobotka, T., \& Toulemon, L. (2008). Overview chapter 4: Changing family and partnership behaviour: Common trends and persistent diversity across Europe. Demographic Research, 19, 85-138.

Starkey, J. L. (1996). Race differences in the effect of unemployment on marital instability: A socioeconomic analysis. The Journal of Socio-Economics, 25(6), 38.

Steiber, N. (2009). Reported levels of time-based and strain-based conflict between work and family roles in Europe: A multilevel approach. Social Indicators Research, 93(3), 469-488. https://doi.org/10. 1007/s11205-008-9436-z.

Storesletten, K., Telmer, C. I., \& Yaron, A. (2004). Cyclical dynamics in idiosyncratic labor market risk. Journal of Political Economy, 112(3), 695-717. https://doi.org/10.1086/383105.

Todesco, L. (2009). Chi paga per la rottura? Le conseguenze economiche dell'instabilità coniugale in Italia. Polis, 1, 83-114. https://doi.org/10.1424/29385.

Vignoli, D., \& Ferro, I. (2009). Rising marital disruption in Italy and its correlates. Demographic Research, 20, 11-36.

Vignoli, D., Bazzani, G., Guetto, R., Minello, A., \& Pirani, E. (2020a). Uncertainty and narratives of the future. A theoretical framework for contemporary fertility. In R. Schoen (Ed.), Analyzing contemporary fertility (pp. 25-47). Springer.

Vignoli, D., Guetto, R., Bazzani, G., Pirani, E., \& Minello, A. (2020b). A reflection on economic uncertainty and fertility in Europe: The narrative framework. Genus, 76(28), 1-27. https://doi.org/10.1186/ s41118-020-00094-3.

Vignoli, D., Matysiak, A., Styrc, M., \& Tocchioni, V. (2018). The positive impact of women's employment on divorce: Context, selection, or anticipation? Demographic Research, 38, 1059-1110. https://doi.org/ 10.4054/DemRes.2018.38.37.

Vignoli, D., Tocchioni, V., \& Mattei, A. (2020c). The impact of job uncertainty on first-birth postponement. Advances in Life Course Research. https://doi.org/10.1016/j.alcr.2019.100308.

Vignoli, D., Tocchioni, V., \& Salvini, S. (2016). Uncertain lives: Insights into the role of job precariousness in union formation in Italy. Demographic Research, 35, 253-282. https://doi.org/10.4054/DemRes. 2016.35.10.

Virtanen, M., Kivimäki, M., Joensuu, M., Virtanen, P., Elovainio, M., \& Vahtera, J. (2005). Temporary employment and health: A review. International Journal of Epidemiology, 34(3), 610-622. https://doi. org/10.1093/ije/dyi024.

Whelan, C. T. (1994). Social class, unemployment, and psychological distress. European Sociological Review, 10(1), 49-61. https://doi.org/10.1093/oxfordjournals.esr.a036315.

Publisher's Note Springer Nature remains neutral with regard to jurisdictional claims in published maps and institutional affiliations. 